
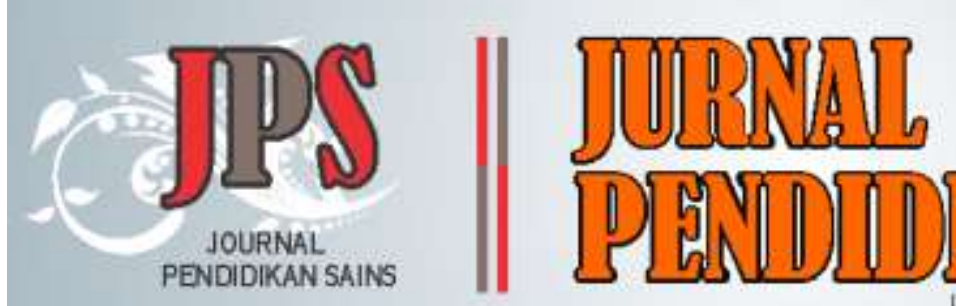

p-1SSN : 2339-0786 o-15SN:2502-1443

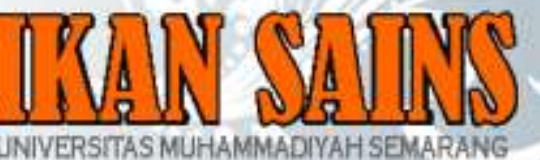

\title{
The Effect Of Problem-Based Learning With Reading Questioning Answering Strategy On Students' Metacognitive Skills Of Acid-Base Concept
}

\author{
Ghiska Primayana Mufhtih $^{1}$, Dedi Irwandi ${ }^{2}$, Evi Sapinatul Bahriah ${ }^{3 *}$ \\ 1,2,3* Chemistry Education, Educational Sciences Faculty, Syarif Hidayatullah State Islamic University Jakarta \\ * corresponding author: evi@uinjkt.ac.id
}

\begin{tabular}{lr}
\hline \multicolumn{2}{l}{ Article history } \\
\hline Submission & $: 2021-10-12$ \\
Revised & $: 2021-10-24$ \\
Accepted & $: 2021-11-03$ \\
& \\
Keyword & \\
\hline Keywords: & problem-based \\
learning, reading \\
questioning & answering, \\
metacognitive & skills of acid- \\
base
\end{tabular}

\begin{abstract}
Metacognitive skills are one of the skills needed in the 21st century to achieve student learning success. Students' metacognitive skills are still low, so that need to be empowered during the learning process by implementing Problem Based Learning Strategy Integrated with Reading Questioning Answering (PBLRQA). Through the PBLRQA strategy, students can control their cognitive processes by planning, monitoring, and evaluating to solve problems in chemistry learning. This research aimed to determine the effectiveness of the PBLRQA strategy on students' metacognitive skills on acid-base materials. The method was used as a quasi-experiment with a non-equivalent control group design. The sample in this study were students of class XI IPA 1 as the experimental group and students of class XI IPA 5 as the control group, with each class including 32 students. Instruments Metacognitive Activities Inventory (MCA-I) developed by Cooper and Sandi-Urena (2009) were used in this research. Data analysis was assisted by IBM SPSS Statistics 22 software. This research indicated that using the PBLRQA strategy on acid-base materials empowered students' metacognitive
\end{abstract} skills.

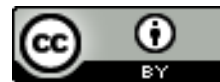

This work is licensed under a Creative Commons Attribution 4.0 International

\section{INTRODUCTION}

The 21 st century is known as a globalization era which demands each individual to adapt to the rapid transformation of life's aspect, especially the development of sciences. This shift needs to be anticipated by optimizing the role of education. Thus, education is expected to help students have the capabilities and skills required for the 21 st century to become successful.

One of the skills needed in this $21 \mathrm{st}$ century to compete in local or international aspects is thinking skills, including critical thinking, problem-solving, creativity, and metacognitive skills (Pratama, 2018). In Indonesia, critical thinking skills are one of the educational aspects which are much concerned. This idea has been regulated in Permendikbud
No. 20 of 2016 concerning graduation standards which stated that thinking skills become mandatory skill students need to achieve in secondary school in terms of the chemistry course. Redhana (2019) asserts that the chemistry course is beneficial to improve skills in the 21 st century.

Metacognitive skills play an essential role in students' learning achievement. It is supported by Nurisya et al. (2017), finding a solid relationship between metacognitive skills and learning results with a value of $72.6 \%$. Students with excellent metacognitive skills will have proper learning achievement academically.

Metacognitive skills are defined as thinking skills that refer to obtained and unobserved knowledge. Students learn how to apply learning skill sets and develop 
simultaneous thinking processes (Muna et al., 2016). Metacognitive skills relate to individuals' capabilities in managing, controlling, and exploring their thinking process consciously toward their learning attitude in solving a problem (Azizah et al., 2019). A metacognitive activity is crucial as it drives students to think critically and arrange, control, and reflect prior thinking activity (Kodri \& Anisah, 2020). Metacognitive skills assist the students in investigating and improving their vulnerability. Hence, it eases students in comprehending learning concepts and making meaningful learning.

There were some studies found that Indonesian students' metacognitive skills were low. Aprilia \& Sugiarto (2013) conducted a study and discovered that students at SMAN 1 Rengel, Tuban had inadequate metacognitive skills. Ratnawati, Rahman \& Gonggo (2015) found that students' metacognitive skills in solving problems in the scope of chemistry were considered low. In addition, Muhlisin et al. (2016) reported that metacognitive skills remained low and dominated for $49 \%$.

One factor that draws on the metacognitive skills to be insufficient is the learning concept used by teachers. Its Has not entirely considered the metacognitive skills, especially in chemistry courses. Sari et al. (2018) argue that conventional teaching methods are still run in learning acid-base, causing students to have no involvement in addressing arguments related to problems, pictures, or narratives, leading students to zero interaction. Passive learning did not force students to actively think and try to construct ideas and comprehension in learning. Chemistry course, especially in the acid-base scope, demands students to have sufficient knowledge of the principal, law, and other abstract chemistry concepts.

Regarding explaining students' metacognitive skills, teachers can consider some strategies to improve students' metacognitive skills. According to Andriani et al. (2019), a strategy used by teachers can be a crucial factor in optimizing students' potential in the scope of sciences. Applying a learning strategy that emphasizes a process can increase students' metacognitive skills. Such learning is a beneficial stimulus for students to participate actively in a class, leading to autonomous learning (constructivism).
Danial (2010) asserts that the PBL strategy can increase students' metacognitive skills. Aisyah \& Ridlo (2015) argue that the PBL strategy can elevate students' metacognitive skills. Indicated by students who apply PBL strategy achieve higher mean scores than the ones who do not. Fitriyani, Corebima \& Ibrohim (2015) discover that the PBL strategy significantly affects students' metacognitive skills. Therefore, it can be assumed that there is a positive effect of PBL strategy on students' metacognitive skills.

PBL is generally defined as a learning environment that focuses on a student-centered application, driving the students to construct their knowledge and work collaboratively to solve problems (Ahamad et al., 2017). Nuryanto, Utami \& Saputro (2015) argue that PBL's utilization prompts students to listen to, take notes, memorize the materials, think critically, find information, cultivate the data, and address and summarize arguments.

Problems are necessary for the implementation of PBL. The problems shown are the stimulus to begin learning activity, and the problems are needed to be solved by the students. Students doing a problem-solving phase of PBL require relevant knowledge and information. On some occasions, students often are reluctant to resolve problems as students have no sufficient related knowledge. Abidin (2017) believes that knowledge, information, experiences, and skills can be acquired through reading.

Prior to the explanation above, Reading Questioning Answering (QRA) strategy is considered appropriate in supporting the implementation of PBL. By employing QRA, reading activities are necessitated to assist the students in coping with problems. Corebima (2009) states that the implementation of QRA can urge students to read materials given, making the planned lesson utilized, and the material understanding can be increased to nearly $100 \%$.

QRA is an active-learning strategy that associates with constructivism (Mulyadi \& Diana, 2018). Syntax in QRA can produce knowledge for students by gathering the information that can be developed through reading, questioning, and answering the provided problem. This strategy allows the students to investigate the subject matters and the critical issues in questions and scrutinize answers from related sources (Iqbal \& Hariyadi, 
2015). Regarding the utilization of the strategy, the students can do a self-monitoring, selfmanaging, and self-assessment of their learning activity (Lashari, Lisa \& Julung, 2017). Thus, monitoring and assessing are part of metacognitive skills. It is relevant with Darussyamsu \& Fadilah (2017) that QRA learning strategy can improve students' metacognitive and learning outcomes.

Based on the explanation above, the researchers decided to select the Problem-based Learning with Reading Questioning Answering Strategy (PBLRQA) that is considered beneficial to improve students' metacognitive skills of acid-base materials. PBL was in line with Bahri \& Idris (2017) found that students can implement PBLRQA to increase their metacognitive skills. This research was conducted with a sample of students from the Biology Department, not high school students. The implementation of PBLRQA was expected to elevate students' metacognitive skills of acidbase learning materials, leading to excellent outcomes. Hence, the researchers proposed a study entitled "The Effect of Problem-based Learning with Reading Questioning Answering Strategy on Students' Metacognitive Skills of Acid-Base Concept."
This study employed two variables consisting of one dependent variable and one independent variable. The independent variable was the PBLRQA strategy and a conventional strategy. The research method used was a quasiexperiment with a non-equivalent control group design, referring to a research design with an experimental and a control group that applied no random selection (Sugiyono, 2009, p. 79). The non-equivalent control group design is shown in Table 1.

Table 1. Research Design of Non-equivalent Control Group

\begin{tabular}{cccc}
\hline Group & Pretest & Treatment & Posttest \\
\hline Experimental & $\mathrm{O}_{1}$ & $\mathrm{X}$ & $\mathrm{O}_{2}$ \\
\hline Control & $\mathrm{O}_{1}$ & $\mathrm{Y}$ & $\mathrm{O}_{2}$ \\
\hline
\end{tabular}

The research was conducted in SMA Negeri 4 South Tangerang, starting from 27th January to 14th February 2020, focusing only on acid-base learning materials in the scope of chemistry. This study involved 64 students consisting of two groups, and each group contained 32 students for the experimental group (XI IPA 1) and the control group (X1 IPA 5). This research used a metacognitive skill questionnaire adopted from Cooper \& SandiUrena's Metacognitive Activities Inventory (MCA-I) (2009). Hence, the blueprint of the metacognitive skill instrument is displayed in Table 2.

\section{RESEARCH METHOD}

Table 2. The Blueprint of Metacognitive Skills Instrument

\begin{tabular}{ccc}
\hline No. & Aspects & Item Number \\
\hline 1. & Planning & $1,3,5,6,7,8,11,13,14,17,19$ \\
\hline 2. & Monitoring & $2,9,12,15,16,18,20,21,22,23,24,25,26,27$ \\
\hline 3. & Evaluating & 4,10 \\
\hline
\end{tabular}

This study employed three steps: preparation, implementation, and finalization.
The three steps somehow can be seen in Figure 1 below. 


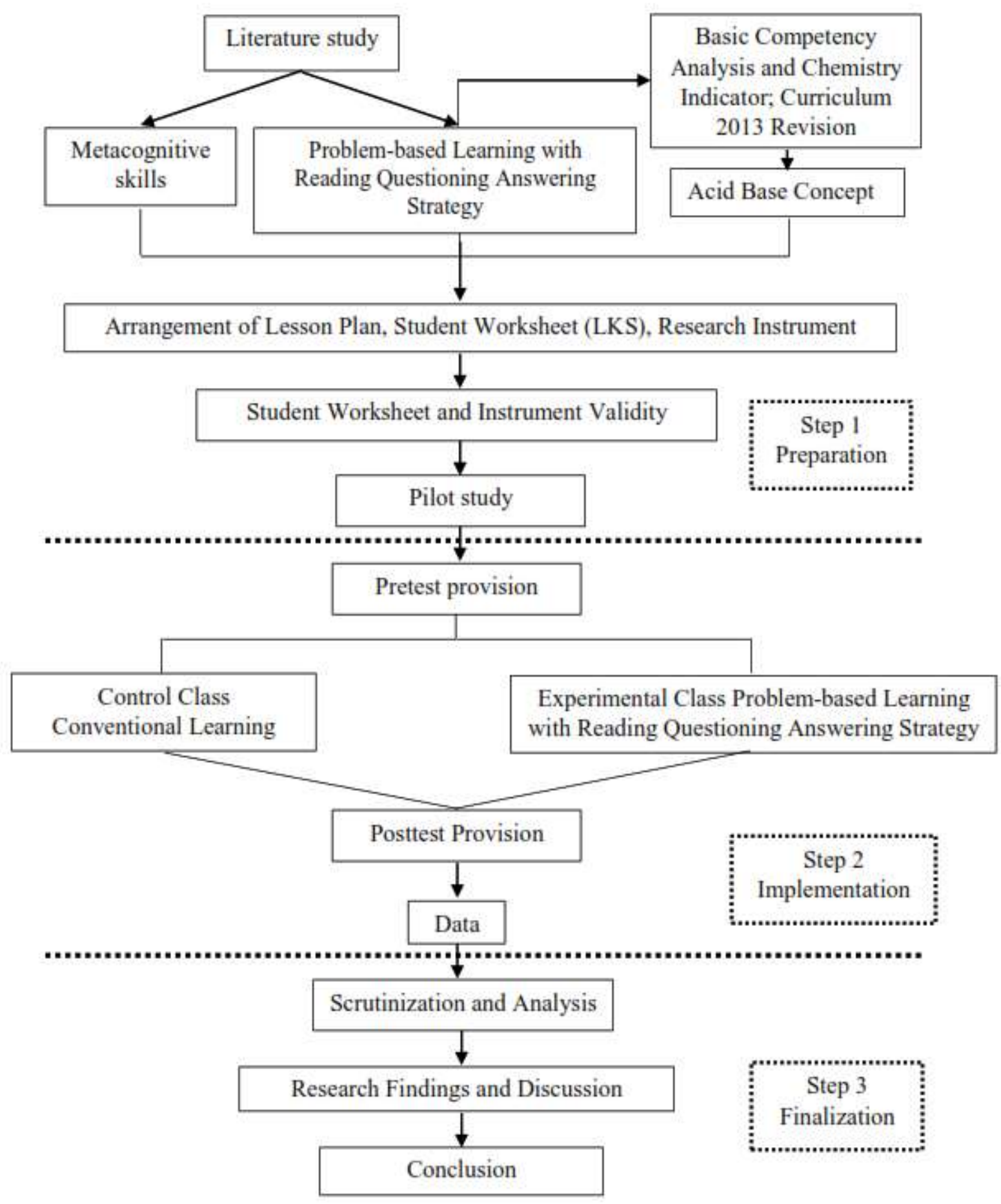

Figure 1. Research Procedure

There are some steps to do in analyzing data of students' metacognitive skills:

1. Granting score for each student's response in the questionnaire $\mathrm{N}: \frac{\text { Gathered score }}{\text { Ideally maximum score }} \times 100$

2. Calculating each student's total score

3. Calculating each given question's total score

4. Converting the total score to be on the scale of $0-100$ by proposing a formula:

5. Calculating the average score of each metacognitive-skill aspect

6. Interpreting the percentage into a category of excellent, good, fair, poor, 
and bad, based on (Purwanto, 2004, p. 103)

7. Conducting prerequisite test, namely normality and homogeneity test by IBM SPSS Statistic 22 software

8. Conducting hypothesis test using nonparametric data test Mann-Whitney by IBM SPSS Statistic 22 software

\section{FINDINGS AND DISCUSSION}

In regards to the preparation phase, the instrument used in this study was adhered to be validated. The instrument of MCA-I containing 27 questions was also needed to be validated. Besides, some learning tools utilized were validated. The PBLRQA-based student's worksheet used for three meetings was also necessitated to be validated by experts.

This study was conducted based on the lesson plan; it should run for five classes meetings. The meeting started with a pretest and proceeded with a teaching-learning activity in the two classes. The student worksheet was distributed for each class based on the selection of learning strategies determined. The experimental class utilized the PBLRQA strategy, and the control one applied the conventional teaching-learning method.

The data was gathered from the pretest and posttest of students' metacognitive skills. The result of students' metacognitive skills in the pretest and posttest was displayed in Figure 2.

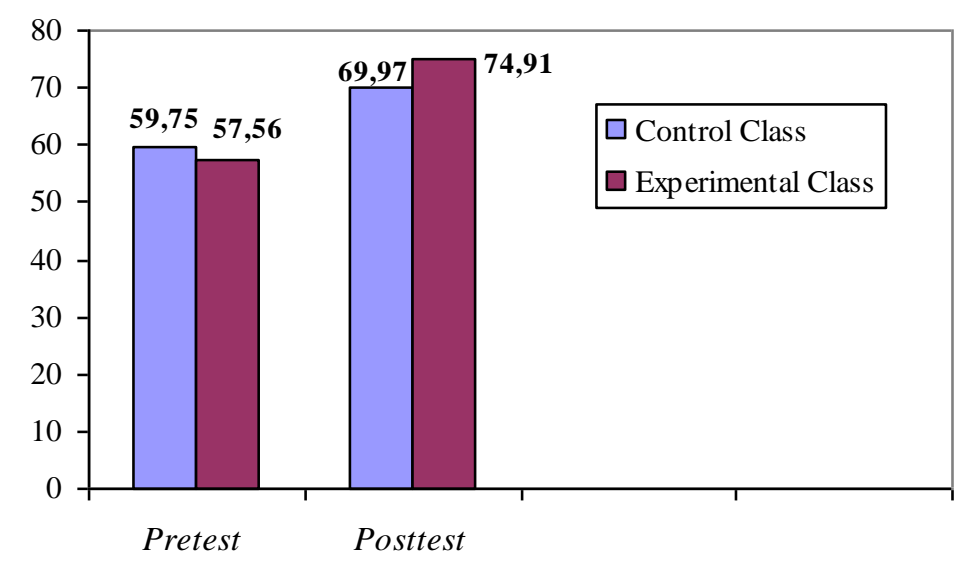

Figure 2. The Data of Students' Metacognitive Skills

Figure 2 showed that there was a significantly different result between the control group and the experimental one. Hence, it can be assumed that different treatments given to the two groups can influence students' metacognitive skills. Students in the experimental group who got treatment from PBLRQA obtained a higher average score than the control one, which runs the conventional teaching-learning method.

Furthermore, normality tests and homogeneity tests were done as the prerequisite step in analyzing data. A normality test was run to see whether data were normally distributed. In addition, the normality test in this study referred to Kolmogorov-Smirnov measurement with the significance level of 0,05 . If the value $>\alpha(0,05)$, the data would be considered normal. Moreover, the standard data distribution was only revealed in the posttest of the experimental group with Sig. 0,200. Regarding the pretest result in the control group and pretest and posttest in the experimental group, there was no normal data distribution since the significance values were 0,004, 0,000, 0,000, respectively.

A homogeneity test was done to see if the data was homogenous. This study conducted One-way ANOVA with the significance level of 0,05 . If the Sig. $>\alpha(0,05)$, the data was considered normal. From the data calculation, it can be seen that the result of pretest $(0,676)$ and posttest $(0,271)$ was homogenous.

Hypothesis testing was determined by normality and homogeneity test, and the data of this study was unable to run parametric statistics; one of them was an independent sample t-test. As a result, this study employed a non-parametric test with Mann-Whitney measurement. Using such measurement in statistics examined the significance value of metacognitive skills between the control and experimental groups. Sig determined data interpretation. Value (2-tailed). If the Sig. value (2-tailed) $<$ alpha $(\alpha=0,05)$, the null hypothesis 
would be rejected. The pretest resulted in Sig. value (2-tailed) for $0,073>0,05$. It meant no significantly different result of students' metacognitive skills in the control and experimental groups. In terms of posttest, the result of significance (2-tailed) level was $0,000<0,05$. It implied that students' metacognitive skills were significantly different in the control and experimental groups after treatment was given in the experimental one.
Hence, this indicated that there was an effect of the PBLRQA strategy on students' metacognitive skills.

There were three aspects of metacognitive skills measured in this study: planning, monitoring, and evaluating. The data calculation of the posttest result can identify each aspect of students' metacognitive skills. The result of students' metacognitive aspects in the posttest was shown in Table 3.

Table 3. Metacognitive Skills Achievement

\begin{tabular}{ccccc}
\hline $\begin{array}{c}\text { Metacognitive Skills } \\
\text { Aspects }\end{array}$ & $\begin{array}{c}\text { Control } \\
\text { Class }\end{array}$ & Category & $\begin{array}{c}\text { Experimental } \\
\text { Class }\end{array}$ & Category \\
\hline Planning & $73,84 \%$ & Fair & $78,14 \%$ & Good \\
\hline Monitoring & $61,23 \%$ & Fair & $69,06 \%$ & Fair \\
\hline Evaluating & $78,75 \%$ & Good & $85,00 \%$ & Good \\
\hline
\end{tabular}

Based on Table 3, it can be viewed that the experimental group had higher achievement than the control group in terms of the three aspects of metacognitive skills. The planning aspect in the experimental group was considered good, with a value of $78,14 \%$. This result thus was influenced by the application of the PBLRQA strategy in a class. According to Celiker (2015), PBL can develop students' metacognitive skills through a problem-solvingbased activity. Besides, reading activities, asking questions, and preparing the answers in the syntax of QRA was crucial in improving students' planning skills. Students were asked to find and read some sources relating to given issues. Catalano (2017) argues that students involve their metacognitive skills in digging pieces of information. Mulyadi et al. (2014) also support the idea that students use their metacognitive skills in comprehending texts. Giving assignments that require formulating questions and predicting answers assists students in solving problems. Hariyadi et al. (2017) believe students arrange questions and answers to break down and solve the problems from their perspectives. Colbert et al. (2014) then assert that a questioning strategy encourages students to grasp the information about the problems comprehensively, leading them to improve their metacognitive skills. Hidayat et al. (2020) argue that a planning aspect can help students forecast problems in the future, encouraging them to plan strategies in learning to achieve better results.

The monitoring aspect in the experimental group obtained a higher result $(69,06 \%)$ than the one in the control class $(61,23 \%)$. The monitoring aspect consisted of self-assessment skills essential in arranging students' learning activities (Mahdavi, 2014). The aspect referred to students' critical analysis of strategies and plans during the learning process. The monitoring aspects can be considered more flourished because of the implementation of the PBLRQA strategy. The strategy can assist students in improving their comprehension in solving problems. When applying the PBLRQA strategy, students intended to present their learning output related to the problem given. This learning activity then helped the students to get assessment and feedback from their peers or teachers about their prior knowledge. Thus, the learning scenario can trigger students' monitoring skills (Mathabathe \& Potgieter, 2014).

The monitoring aspect had the lowest result in the experimental class. Such a result was determined by students' insufficient knowledge in selecting suitable strategies for solving the problem, and the factor often occurred (Syahmani \& Borneo, 2017). Another factor was influenced by cognitive aspects (Efklides, 2014). Each student had different cognitive skills, whereas metacognitive skills are the core of the cognitive aspects in controlling someone's thoughts. Anggo (2011) believes that metacognitive and cognitive skills can be separated as these two aspects are incorporated in someone's thoughts.

Students achieved the highest result in the experimental class regarding the evaluation aspect with a value of $85,00 \%$. This result indicated that students' evaluation skills had a better improvement. In addition, the highest result was determined by the PBLRQA strategy. 
In the learning activity, students were expected to do self-assessment and reflection. The evaluation aspect was supported by syntax in the PBLRQA strategy, providing spaces for analyzing and evaluating prior problem-solving activities. In this phase, students reflected on trial procedures, thinking that the data obtained can answer the given problems, considering whether a set of goals can be achieved or not, and thinking of some solutions in collecting the data in the field more precisely. The prior statement is supported by Opstal \& Daubenmire (2015), describing students using the evaluation aspect to reflect on strategies and goals utilized in the learning process and whether the students can solve the problem or not. Likewise, the PBLRQA strategy led students to solve problems collaboratively, work cooperatively, and communicate with their peers. According to Djamahar et al. (2019), self-monitoring and correction can be established when someone communicates with their peers. Yasir et al. (2020) argue that evaluation skills are beneficial for students in comprehending what learning strategies are suitable for their learning needs.

The differences in students' outcomes related to the aspects of metacognitive skills were shaped by the different academic backgrounds of each student. Students who had higher academic proficiency tended to have better metacognitive skills. Muhlisin et al. (2016) claim that students who have higher academic proficiency were considered more capable of arranging and selecting suitable strategies in finishing tasks and capable of evaluating the activity they had done rather than the ones who have lower proficiency.

PBLRQA strategy applied in the experimental group was designed to have practical training for the students. Haryani et al. (2014) argue that doing practical training in a laboratory, such as asking questions, checking trial procedures, evaluating data investigations, and elaborating ideas, is an activity that involves students' metacognitive skills. Sarıbaş \& Bayram (2016) assert that such activity is part of the metacognitive activity. Syntax contained in the PBLRQA strategy made the strategy considered as constructivism-based learning. According to Bahri \& Idris (2017), students can raise their metacognitive skills by applying constructivism-based learning. In this part, teachers only play a role as a facilitator, driving the students to construct self-learning concepts and comprehension. Yusnaeni \& Corebima
(2017) state that students who are autonomous in learning will have better metacognitive skills.

Based on the explanation above, it can be seen that the PBLRQA strategy effectively improved students' metacognitive skills in the scope of acid-based learning. The three aspects of students' metacognitive skills in the experimental group can establish. The PBLRQA strategy helped students elevate their metacognitive skills. Thus, the findings of this study were in line with Bahri et al. (2019), suggesting that the PBLRQA strategy was applicable in improving students' metacognitive skills rather than the conventional one.

\section{CONCLUSION}

Based on the findings above, it can be concluded that using Problem-based Learning with Reading Questioning Answering Strategy in learning acid-base can improve students' metacognitive skills. The evidence can be seen when each aspect of students' metacognitive skills in the experimental group resulted in values of $78,14 \%$ for the planning aspect, $69,06 \%$ for the observation aspect, and $85,00 \%$ for the evaluation aspect.

The current study's researchers suggested that other scholars provide much time to apply Problem-based Learning with Reading Questioning Answering Strategy. The scholars for future study need to ensure that the students are heterogenous to encourage the students to get involved in learning circumstances.

\section{REFERENCES}

Abidin, Z. (2017). Meningkatkan Keterampilan Membaca Siswa Kelas XI IPA 6 melalui Metode SQ3R SMA Negeri 1 Bontonompo, Kecamatan Bontonompo, Kabupaten Gowa. Jurnal Nalar Pendidikan, 5(1), 55-63.

Ahamad, S. N. S. H., Li, H. C., Shahrill, M., \& Prahmana, R. C. I. (2017). Implementation of Problem-Based Learning in Geometry Lessons. Journal of Physics: Conference Series, 943(1), 1-14.

Aisyah, S., \& Ridlo, S. (2015). Pengaruh Strategi Pembelajaran Jigsaw dan Problem Based Learning terhadap Skor Keterampilan Metakognitif Siswa pada Mata Pelajaran Biologi. Unnes Journal of Biology Education, 4(1), 22-28.

Andriani, D., Marpaung, R. R. T., \& Jalmo, T. (2019). Pengaruh Model Problem Based Learning terhadap Keterampilan 
Metakognisi dan Hasil Belajar Siswa. Jurnal Bioterdidik, 7(1), 22-31.

Anggo, M. (2011). Pelibatan Metakognisi dalam Pemecahan Masalah Matematika. Edumatica, 01(01), 25-32.

Aprilia, F., \& Sugiarto, B. (2013). Keterampilan Metakognitif Siswa melalui Penerapan Model Pembelajaran Inkuiri Terbimbing pada Materi Hidrolisis Garam. Unesa Journal of Chemical Education, 2(3), 3641.

Azizah, U., Nasrudin, H., \& Mitarlis. (2019). Metacognitive Skills: A Solution in Chemistry Problem Solving. Journal of Physics: Conference Series, 1417, 1-8.

Bahri, A., \& Idris, I. S. (2017). Teaching Thinking: Memberdayakan Keterampilan Metakognitif Mahasiswa melalui PBLRQA (Integrasi Problem-based Learning dan Reading, Questionin, \& Answering). Jurnal Seminar Nasional Lembaga Penelitian UNM, 59-69.

Bahri, A., Idris, I. S., Nurman, R., \& Ristiana, E. (2019). PBLRQA Strategy Potential in Enhancing Metacognitive Skills of Students with Different Academic Achievement. Journal of Physics: Conference Series, 1317, 1-8.

Catalano, A. (2017). Development and Validation of the Metacognitive Strategies for Library Research Skills Scale (MSLRSS). The Journal of Academic Librarianship, 43(3), 178-183.

Celiker, H. D. (2015). Development of Metacognitive Skills: Designing Problembased Experiment with Prospective Science Teachers in Biology Laboratory. Academic Journals, 10(11), 1487-1495.

Colbert, C. Y., Graham, L., West, C., White, B. A., Arroliga, A. C., Myers, J. D., Ogden, P. E., Archer, J., Mohammad, Z. T. A., \& Clark, J. (2014). Teaching Metacognitive Skills: Helping Your Physician Trainees in the Quest to "Know What They Do not Know." The American Journal of Medicine, 1-16.

Cooper, M. M., \& Sandi-Urena, S. (2009). Design and Validation of an Instrument To Assess Metacognitive Skillfulness in Chemistry Problem Solving. Journal of Chemical Education, 86(2), 240-245.

Corebima, A. D. (2009). Pengalaman Berupaya menjadi Guru Profesional. Pidato Pengukuhan Guru Besar, 1-100.

Danial, M. (2010). Pengaruh Strategi PBL terhadap Keterampilan Metakognisi dan Respon Mahasiswa. Jurnal Chemica, 11(2), 1-10.

Darussyamsu, R., \& Fadilah, M. (2017). Pengaruh Strategi Pembelajaran Reading, Questioning and Answering terhadap Kemampuan Berpikir Kreatif Mahasiswa Jurusan Biologi FMIPA Universitas Negeri Padang pada Matakuliah Evolusi. Bioeducation Journal, 1(1), 10-21.

Djamahar, R., Ristanto, R. H., Sartono, N., Ichsan, I. Z., Darmawan, E., \& Muhlisin, A. (2019). Empowering Students' Metacognitive Skill through Cirsa Learning. Journal of Physics: Conference Series, 1227, 1-8.

Efklides, A. (2014). How Does Metacognition Contribute to the Regulation of Learning? An Integrative Approach Anastasia. Psychological Topics, 23(1), 1-30.

Fitriyani, R., Corebima, A. D., \& Ibrohim. (2015). Pengaruh Strategi Pembelajaran Problem Based Learning dan Inkuiri Terbimbing terhadap Keterampilan Metakognitif, Berpikir Kritis, dan Hasil Belajar Kognitif Siswa SMA. Jurnal Pendidikan Sains, 3(4), 186-200.

Hariyadi, S., Aloysius, D. C., Zubaidah, S., \& Ibrohim. (2017). The Comparison of the Question Types in the QRA (Reading, Questioning, and Answering) Learning Model and Conventional Learning Model. International Journal of Humanities Social Sciences and Education (IJHSSE), 4(7), $10-18$.

Haryani, S., Prasetya, A. T., \& Permanasari, A. (2014). Developing Metacognition of Teacher Candidates by Implementing Problem Based Learning within the Area of Analytical Chemistry. International Journal of Science and Research (IJSR), 3(6), 1223-1229.

Hidayat, S., Rojabi, Y. N., \& Rahmawati, N. A. (2020). Profil Keterampilan Metakognitif Peserta Didik pada Konsep Bakteri Kelas X MIPA di Kota Tasikmalaya. Quagga: Jurnal Pendidikan Dan Biologi, 12(2), 176-180.

Iqbal, M., \& Hariyadi, S. (2015). Pengaruh Implementasi Strategi RQA (Reading, Questioning, Answering) pada Matakuliah Pengantar Teknologi Informasi dalam Meningkatkan Hasil Belajar Mahasiswa. Prosiding Seminar Nasional Pendidikan Sains, 1421-1423. 
Peraturan Menteri Pendidikan dan Kebudayaan No. 20 Tahun 2016 tentang Standar Kelulusan, (2016).

Kodri, \& Anisah, A. (2020). Analisis Keterampilan Metakognitif Siswa Sekolah Menengah Atas dalam Pembelajaran Ekonomi Abad 21 di Indonesia. Edunomic Jurnal Pendidikan Ekonomi Fakultas Keguruan Dan Ilmu Pendidikan, 8(1), 919.

Lashari, D. A., Lisa, Y., \& Julung, H. (2017). Pengaruh Model Reading Questioning Answering (RQA) terhadap Pengetahuan Metakognitif Siswa pada Materi Sistem Pernapasan Manusia. JPBIO (Jurnal Pendidikan Biologi), 2(2), 27-33.

Mahdavi, M. (2014). An Overview: Metacognition in Education. International Journal of Multidisciplinary and Current Research, 2, 529-535.

Malahayati, E. N., Corebima, A. D., \& Zubaidah, S. (2015). Hubungan Keterampilan Metakognitif dan Kemampuan Berpikir Kritis dengan Hasil Belajar Biologi Siswa SMA dalam Pembelajaran Problem Based Learning (PBL). JPS (Jurnal Pendidikan Sains), 3(4), 178-185.

Mathabathe, K. C., \& Potgieter, M. (2014). Metacognitive Monitoring and Learning Gain in Foundation Chemistry. The Royal Society of Chemistry 2014, 15(1), 94-104.

Muhlisin, A., Susilo, H., Amin, M., \& Rohman, F. (2016). Analisis Keterampilan Metakognitif ditinjau dari Kemampuan Akademik Berbeda pada Perkuliahan Konsep Dasar IPA. Prosiding Seminar Nasional Biologi 2016, 493-496.

Mulyadi, Adlim, \& Djufri. (2014). Memberdayakan Kemampuan Berpikir Mahasiswa melalui Model Pembelajaran Reading Questioning and Answering (RQA). Jurnal Biotik, 2(1), 33-37.

Mulyadi, \& Diana, E. (2018). Meningkatkan Keaktifan Mahasiswa dalam Berdiskusi melalui Model Pembelajaran Reading, Questioning and Answering. Prosiding Seminar Nasional Biotik, 710-715.

Muna, K., Haryani, S., \& Susilaningsih, E. (2016). Pengaruh Guided Inquiry Learning terhadap Keterampilan Metakognisi Siswa dalam Materi Kelarutan dan Hasil Kali Kelarutan. Journal of Innovative Science Education, 5(1), 19-27.

Nurisya, K., Corebima, A. D., \& Rohman, F.
(2017). Analisis Perbandingan Hubungan Antara Keterampilan Metakognitif terhadap Hasil Belajar dan Retensi Siswa SMA pada Pembelajaran Biologi Berbasis PBL. Jurnal Pendidikan, 2(2), 246-251.

Nuryanto, Utami, B., \& Saputro, A. N. C. (2015). Penerapan Model Pembelajaran Problem Based Learning (PBL) dilengkapi Macromedia Flash untuk Meningkatkan Kemampuan Berpikir Kritis dan Prestasi Belajar Siswa pada Materi Pokok Termokimia Kelas XI Siswa SMA Negeri 2 Karanganyar Tahun Pelajaran 2014/2015. Jurnal Pendidikan Kimia (JPK), 4(4), 87-94.

Opstal, M. T. van, \& Daubenmire, P. L. (2015). Extending Students' Practice of Metacognitive Regulation Skills with the Science Writing Heuristic. International Journal of Science Education, 37(7), 1089-1112.

Pratama, A. T. (2018). Improving Metacognitive Skills using Problem Based Learning (PBL) at Natural Science of Primary School in Deli Serdang Indonesia. Biosfer: Jurnal Pendidikan Biologi, 11(2), 101107.

Purwanto, N. (2004). Prinsip-prinsip dan Teknik Evaluasi Pengajaran. Bandung: PT Remaja Rosadakarya.

Putra, H. D., Thahiram, N. F., Ganiati, M., \& Nuryana, D. (2018). Kemampuan Pemecahan Masalah Matematis Siswa SMP pada Materi Bangun Ruang. JIPM (Jurnal Ilmiah Pendidikan Matematika), 6(2), 82-90.

Ratnawati, M., Rahman, N., \& Gonggo, S. T. (2015). Perilaku Metakognisi Siswa dalam Menyelesaikan Masalah Kimia. E-Jurnal Mitra Sains, 3(2), 9-16.

Redhana, I. W. (2019). Mengembangkan Keterampilan Abad Ke-21 Dalam Pembelajaran Kimia. Jurnal Inovasi Pendidikan Kimia, 13(1), 2239-2253.

Sari, A. P., Rudibyani, R. B., \& Efkar, T. (2018). Efektivitas Problem Based Learning untuk Meningkatkan Keterampilan Berpikir Luwes Siswa pada Materi Asam Basa. Jurnal Pendidikan Dan Pembelajaran Kimia (JPPK), 7(2), 1-19.

Sarıbaş, D., \& Bayram, H. (2016). Investigation of the Effects of Using Metacognitive Activities in Chemistry Laboratory on the Development of Conceptual Understanding. Boğaziçi University 
Journal of Education, 33(1), 27-49.

Sugiyono. (2009). Metode Penelitian Kuantitatif, Kualitatif dan $R \& D$. Bandung: CV Alfabeta.

Syahmani, \& Borneo, D. C. F. U. (2017). The Differences of Students Learning Outcomes and Metacognitive Skills by Using PBL and Metacognitive-PBL. Advances in Social Science, Education and Humanities Research, 100, 249-255.

Yasir, M., Fikriyah, A., Qomaria, N., \& Al Haq, A. T. (2020). Metacognitive Skill on
Students of Science Education Study Program: Evaluation from Answering Biological Questions. JPBI (Jurnal Pendidikan Biologi Indonesia), 6(1), 157164.

Yusnaeni, \& Corebima, A. D. (2017). Empowering Students' Metacognitive Skills on SSCS Learning Model Integrated with Metacognitive Strategy. The International Journal of Social Sciences and Humanities Invention, 4(5), 34763481. 